\title{
Knowledge, Attitude and Use of Information Communication Technology (ICT) among English Language Teachers
}

\author{
Dheventhiran Dass Ramadass, Parilah Mohd Shah \\ Faculty of Education, Universiti Kebangsaan Malaysia, Bangi, Malaysia \\ Email:p105787@siswa.ukm.edu.my
}

How to cite this paper: Ramadass, D. D., \& Shah, P. M. (2022). Knowledge, Attitude and Use of Information Communication Technology (ICT) among English Language Teachers. Creative Education, 13, 658-674. https://doi.org/10.4236/ce.2022.132041

Received: January 6, 2022

Accepted: February 20, 2022

Published: February 23, 2022

Copyright ( 2022 by author(s) and Scientific Research Publishing Inc. This work is licensed under the Creative Commons Attribution International License (CC BY 4.0).

http://creativecommons.org/licenses/by/4.0/

\section{(c) (i) Open Access}

\begin{abstract}
The emergence of Information Communication Technology (ICT) over the years has brought significant benefits in the field of education especially for teachers. In the contemporary day, ICT is being used as a synchronous and asynchronous teaching and learning platform that caters to both teachers and learners' needs. The Ministry of Education (MoE) has executed different paradigms to assist teachers in implementing a variety of ICT-supported methods and resources in the classroom to improve the teaching and learning process. This study aims to analyze the level of knowledge, attitude and use of ICT possessed by English language teachers in teaching English. A survey questionnaire consisting of five sections was distributed randomly to English language teachers from various schools around Klang Valley, Malaysia. The findings of the study revealed that the research respondents have adequate knowledge in utilising mundane applications and have positive attitudes toward the use of ICT. Nevertheless, there were several challenges that English language teachers seldom face when implementing ICT in the teaching and learning environment. The results obtained in this research show significant relationship between the knowledge, attitude and the use of ICT among English language teachers.
\end{abstract}

\section{Keywords}

Information Communication Technology (ICT), Teaching and Learning, Knowledge, Attitude, Use, Challenges

\section{Introduction}

ICT is a platform that meets the needs of both educators and learners, and it is vital to note that the teaching and learning processes can take place either synchronously or asynchronously on this platform. As a result, implementing ICT 
in the educational context helps to improve teachers' and students' skills and knowledge. ICT is a platform that facilitates distant learning, which occurs when a teaching and learning process takes place without students or respondents being physically present in the classroom. On the other hand, it is an assuring technology designed to engage students in independent learning via mediums which uses electronic technologies for communication between students and teachers (Beketova et al., 2020; Silverthorne, 2001).

Due to the closure of educational institutions, the pandemic prompted educators to explore the use of online technologies and ICT in carrying out the teaching and learning process. Online educational developments in Malaysia have recently been highlighted as a benefit for face-to-face interactions. The Ministry of Education Malaysia had directed educators to utilise accessible web-based learning tools to enhance the teaching and learning process during school closure due to the unexpected execution of Movement Control Order (MCO). As ICT in education is not yet widely implemented in Malaysia, there are several factors and variables that can influence educators' attitudes and use of ICT in education. ICT in education can be defined as a hierarchical process which involves teaching and learning with the support of certain medium and technology (Awang et al., 2018).

This study aims to investigate the level of knowledge, attitude of the English language teachers and the use of Information Communication Technology (ICT) possessed by English Language teachers. This study will also look into the challenges experienced by English language teachers in making full use of ICT as a teaching and learning platform. The transfer from face-to-face teaching to the adoption of online learning via Information Communication Technology (ICT) platforms has excellently facilitated the process of teaching and learning. The purpose of this study is to accentuate: what are the aspects that limit the English language teachers in using ICT as a teaching and learning tool? Along the line, this research studies on how teachers perceive in using ICT as a teaching and learning platform, teachers' knowledge in using ICT, the attitude of teachers in using ICT, the use of ICT and the challenges that they face in using ICT when it comes to teaching English Language. As an educator and researcher, I am aware that there will definitely be some shortcomings or challenges faced by English language teachers in implementing ICT. Therefore, the challenges faced by English language teachers are also being highlighted in this study. The results obtained in this research show significant relationship between the knowledge, attitude and the use of ICT among English language teachers.

\section{Literature Review}

There are several studies that highlight the significant of Information Communication Technology (ICT) in the field of education. Study conducted by Venkateswar, Gopikanta and Rajashree (2020) looked into the attitude of teachers about the use of Information and Communication Technology (ICT) in teaching and 
learning process. The main findings shows that the research results of this study support the results of different studies carried out in different regions of the country and the world, which shows the importance of ICT in education for teachers. There are no significant differences in the relationship between teacher attitudes and gender and region in (Cavas et al., 2009; Kaur, 2012; Ndibalema, 2014; Dixit \& Kaur, 2015; Wilson et al., 2015; Aydin et al., 2017; Ahuja et al., 2019; Beri \& Sharma, 2019). However, a study showed that only $25 \%$ of teachers showed a positive attitude towards the use of ICT (Mahajan, 2016), which contradicts the results of this study. Through the analysis of the results of this study, it can be concluded that the main objective of this study is to compare the attitudes of teachers, which shows that there are no statistically significant differences in the attitudes of teachers regarding gender and their teaching experience. Therefore, it can be said that teachers have a strong and positive attitude towards the use of ICT in the teaching process, because ICT helps teachers to learn more skills and teach effectively by consuming less time. These results correspond with the findings of Papanastasiou \& Angeli (2008); Kamaruddin et al. (2017) and Suparjan (2021), who found that the majority of respondents have a positive attitude towards the use of ICT in education. Therefore, this study story agrees that ICT must be used in all aspects of education.

Hashemi and Kew (2021) conducted a systematic literature review to explore the problems of ICT-based English education. According to the study, the researcher claims that lack of effective training is caused by a lack of teacher confidence. In other words, more efficient ICT training leads to increased confidence in using ICT in English language instruction. The results also reveal that individuals who have effective training and skills in ICTs have an impact on the environment of their classroom, where students are more interactive and participate more actively than those who continue to suffer from a lack of proper training on the use of ICT as supported by (Ekberg \& Gao, 2018; Hashemi \& Kew, 2021). According to the previously mentioned studies, a lack of time is seen as a worldwide barrier when it comes to teaching English in a classroom. Many researchers believe that preparing and organising materials for ICT applications takes a very long time. As a result, it is argued that teaching English classes using ICT necessitates enough time allocation at each step of the lesson. According to Al-Munawwarah (2014), a common and universal hurdle for teachers in employing ICT as a tool in their English language classrooms is definitely lack of time. This paper also strongly advises teachers to prepare themselves through a few online self-training programmes in order to overcome hurdles when it comes to applying ICT in their English language classrooms.

A quantitative methodology research by Ghavifekr \& Rosdy (2015) on the teaching and learning with technology: effectiveness of ICT integration in school shows that technology-based teaching and learning process seems to be more effective than the traditional learning method. This was supported by Ghavifekr \& 
Rosdy (2015) by saying that using ICT tools helps to create an active classroom learning environment that is more fascinating and effective for bot students and teachers. In this study the researchers have used the combination of two different theories were adopted to find out the effectiveness of ICT integration in enhancing the teaching and learning process. The two theories which were adopted in this study are Diffusion of Innovations by Rogers (2003) and Technology Acceptance Model (TAM) by Davis (2003) which lie under Information systems theory. This study depicts the usefulness of using ICT in education for both teachers and students as well. Form the students' perspective, with a shared mean of 1.84, the results reveal that the ICT is useful for students in learning and it boost their motivation to communicate more with their classmates and continuously increases their confidence to engage actively in class. The result of this study shows that ICT is effective in the sense it helps students to gain sufficient knowledge and allows them to be more confident when it comes to exchanging and sharing knowledge with their classmates. Meanwhile looking into the effectiveness among teachers, the results show that teachers are faced with some difficulties in using ICT. According to the research, teachers do not have adequate teaching time to use ICT for teaching and learning purposes, with a mean score of 1.97. It means that there are no undisturbed moments available for instructors to use ICT for effective teaching and learning. With a mean score of 2.08 , the data obtained shows some teachers are compelled and encouraged to use ICT in their classrooms, but a lack of support from school administration hinders and discourages them from doing so. In addition it is stated that, technical assistance for teachers who encounter difficulties, as well as training and professional development for teachers in terms of ICT use in the classroom are offered at a lower rate, with a mean score of 2.83 and 2.86, respectively. Furthermore, the researchers recommendation for future researchers is to conduct the study in major schools in Malaysia namely, Chinese schools, Tamil schools and private schools, rather than focusing solely on public schools.

\section{Conceptual Framework}

For this research two models which are the Diffusion of Innovations by Rogers (2003) and Technology Acceptance Model (TAM) by Davis (2003) were adapted. These models were adapted in the conceptual framework of this study to investigate the influence of ICT knowledge, attitude and use of ICT among English teachers in schools. Rogers' theory is defined as the process by which an innovation is disseminated among the members of a social system through certain channels over time. Diffusion of Innovation Theory provides useful insights into the process of social change as the main elements that ensure a successful spread of an innovation (Robinson, 2009). This theory helps to explain how ICT is embraced by the users. In order to integrate the technology, the process will begin with "knowledge" of the first channel, which represents features of the decision-making unit by ICT users. It culminates with the users' "confirmation" of 
the technology's acceptance and integration. Davis proposed the TAM model in 2003 to investigate ICT-related behaviour (Davis, 2003; Thang et al., 2015; Nardi, 2018). The Technology Acceptance Model (TAM) is an information systems theory that describes how consumers come to accept and use technology on a daily basis. The TAM theory consists of several aspects that characterise the process of users adopting ICT, namely behavioural intent, perceived usefulness, and perceived ease of use.

The proposed framework incorporates several aspects that are directly related to the main objectives of the study which elucidates on how knowledge and perceptions influence the perceived usefulness and the ease of use of ICT integration. It also serves as a clear guideline for the researcher to investigate the interrelationship between the knowledge level, attitude and use of ICT among English language teachers. Teachers' intention to incorporate ICT is the fundamental variable that supports the essential features in the preceding framework such as ease-of-use, flexibility, functionality, integration and accessibility. The outcome of the study is to determine whether is there a difference in the teaching context and how the knowledge on technology use improves the teaching and learning process in an English classroom (Figure 1).

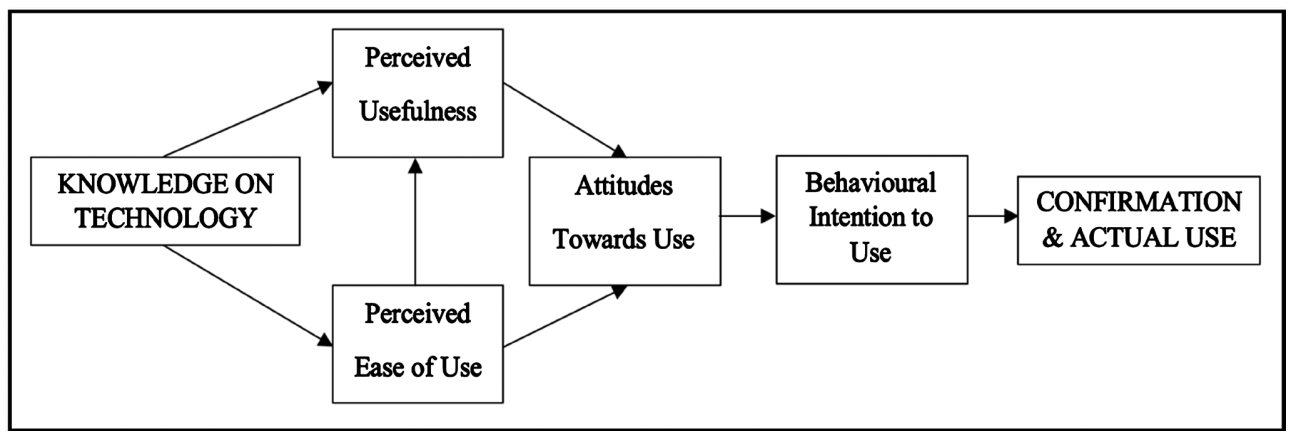

Figure 1. Conceptual Framework for the research (Davis, 2003; Rogers, 2003).

\section{Research Methodology}

\subsection{Research Design}

The research design that was implemented in this study is the descriptive research design which is the survey method. This quantitative method was advantageous as it can be conducted with a set of standardised questions, and it is an ideal method to ask about opinions and attitudes of a particular sample (Nardi, 2018).

\subsection{Research Respondents}

A total number of 80 respondents; 11 male teachers and 69 female teachers participated in this study. The respondents were selected by using the stratified random sampling method. The method of categorising a population into groups is known as stratification (Nickolas et al., 2021). This sampling method is used, to collect data from English language teachers around Klang Valley that comprises the public and private primary schools and secondary schools. 


\subsection{Instrument}

The instrument that was used in this research is a questionnaire which was adapted from Elena C. Papanastasiou and Charoula Angeli (2008), Department of Education, University of Cyprus. The questionnaire was in the form Google Form and the link was given to the respondents to answer the questions. This questionnaire consists of five sections. For section B, C, D and E Likert scale items were be used to obtain the respondents respond as it provides a simple scale for valuing. A Likert scale was used as an ordered scale which enables research respondents to select one option that best represents their point of view. The detail for each section is as described below.

\section{Section A: Teachers' Demographic Information}

In this section, the researcher collected the respondents' gender, school types, their teaching experience, education level and teaching experience. Questions related to demographic information were collected to have a deeper understanding of the research respondents. It is also needed to look for basic information about respondents and it helps me as a researcher to identify the socio-demographic profile of the research respondents.

Section B: Knowledge Level Possessed by English Language Teachers in Using ICT

In Section B the research respondents are required to rate their knowledge on the use of ICT that they have possessed. The questions that were asked are on the knowledge level in using computer, laptop, mobile devices, word processing software, presentation software and internet. There are four Likert scales that were given in each question namely excellent, good, fair and no capability. The respondents are required to tick either scale in the four scales that have been provided.

\section{Section C: English Language Teachers' Attitudes}

This section requires research respondents to respond based on their attitudes upon the use of ICT. The scales listed in this section are 1) Disagree, 2) Neutral, followed by 3) Agree and 4) Completely agree. Research respondents are required to choose either choice that have been listed. The questions for this section aim to find the teachers' attitude in using ICT for teaching and learning process. There are eleven items under this section and research respondents are required to answer all the listed items.

\section{Section D: Level of ICT Use by English Language Teachers}

Section D contains questions regarding English Language teachers' use of ICT for their teaching and learning purpose. Research respondents are required to answer the items on the frequency of ICT use during their teaching and learning. There are eight items under this section and research respondents are required to answer all the listed items. Each question comes with three scales namely 1) Never, 2) Seldom and 3) Often. Only one scale needs to be ticked by the respondent.

Section E: Challenges Faced by English Language Teachers in Using ICT

For the last section, which is section E, research respondents are required to answer items on the challenges faced while using ICT as a teaching and learning medium. Five items were listed under this section and only one scale from three scales 
which are 1) Never, 2) Seldom and 3) Often needs to be ticked by the respondent.

\subsection{Data Collection}

The data were collected in the form of Google Form. The questionnaire link was provided to the research respondents to answer the questions. As we are aware, the Covid-19 pandemic has led to school closure all over Malaysia. Therefore, using Google form helps the researcher to obtain the respond form the respondents more efficiently and the data which is being obtained can be kept orderly in the form of Google form.

\subsection{Data Analysis}

The questionnaire data which were collected for the research respondents will be analysed and evaluated with the use of 'Statistical Package for Social Science (SPSS)' version 27. To obtain the data for the respondents' background, knowledge level in using ICT, attitude towards ICT, use of ICT and the challenges while using ICT, descriptive analysis was conducted. Descriptive statistics are used to characterise the fundamental characteristics of data in the study. It is fundamental in quantitative data analysis. This analysis will help the researcher to obtain more concise summaries of the sample and the intended research questions.

\subsection{Research Process Flowchart}

This research process flowchart helps the researcher to identify the main elements of the research flow while developing and planning it and keep in track of the research flow. The researcher arranges the research flow chronologically as it can be seen in Figure 2. The research process flow map is seen as an evolving diagram in this research as it aids in the identification of less evident aspects of the process, which can subsequently be refined to increase the research efficiency (Figure 2).

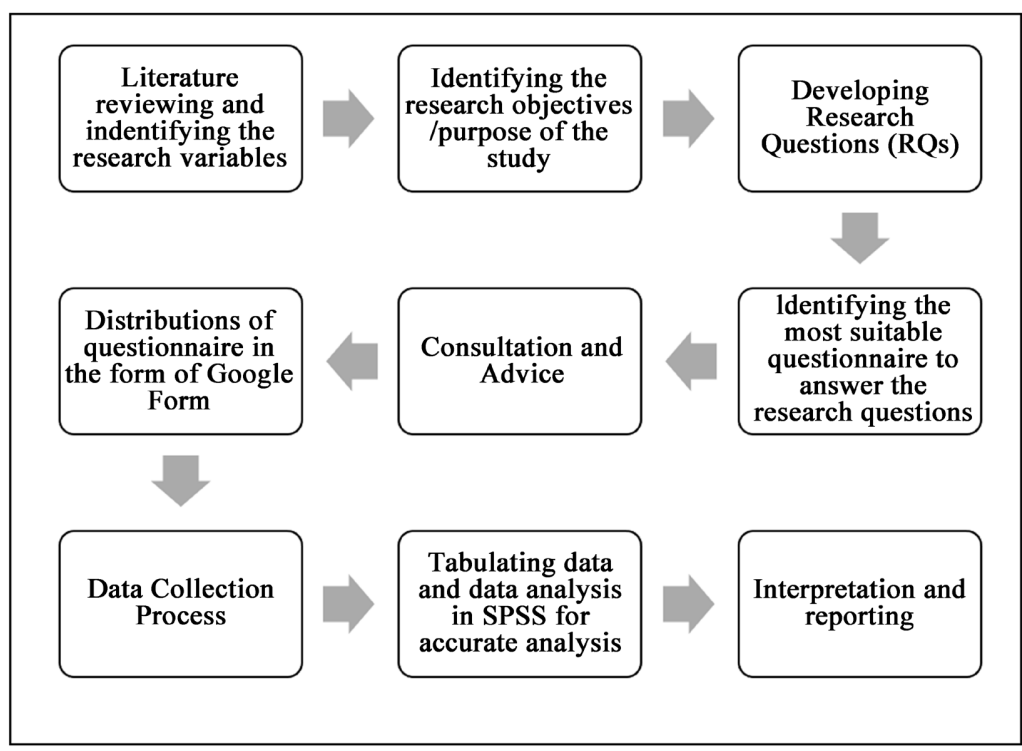

Figure 2. The research process flow chart. 


\section{Research Findings and Discussion}

\subsection{Demographic Background}

Table 1. Gender.

\begin{tabular}{ccc}
\hline Gender & Male & Female \\
\hline $\mathrm{N}$ & 11 & 69 \\
$\%$ & 14 & 86 \\
\hline
\end{tabular}

Table 2. Age group.

\begin{tabular}{ccccc}
\hline Teaching Experience & $\mathbf{2 1 - 3 0}$ & $\mathbf{3 1 - 4 0}$ & $\mathbf{4 1}-\mathbf{5 0}$ & $\mathbf{5 1}-\mathbf{6 0}$ \\
\hline $\mathrm{N}$ & 37 & 17 & 19 & 7 \\
$\%$ & 46 & 21 & 24 & 9 \\
\hline
\end{tabular}

Table 3. School type.

\begin{tabular}{cccc}
\hline School Type & Primary & Secondary & International/Private schools \\
\hline $\mathrm{N}$ & 32 & 31 & 17 \\
$\%$ & 40 & 39 & 21 \\
\hline
\end{tabular}

Table 4. School type.

\begin{tabular}{|c|c|c|c|c|c|c|}
\hline School Type & SK & SJKC & SJKT & SMK & $\begin{array}{l}\text { Boarding School } \\
\text { (SBP) }\end{array}$ & $\begin{array}{c}\text { Private/international } \\
\text { schools }\end{array}$ \\
\hline $\mathrm{N}$ & 18 & 8 & 6 & 23 & 7 & 17 \\
\hline$\%$ & 23 & 10 & 8 & 29 & 9 & 21 \\
\hline
\end{tabular}

Table 5. Experience in teaching.

\begin{tabular}{ccc}
\hline Experience in Teaching & Less than $\mathbf{1 0}$ years & More than 10 years \\
\hline $\mathrm{N}$ & 45 & 35 \\
$\%$ & 56 & 44 \\
\hline
\end{tabular}

Table 6. Using computer.

\begin{tabular}{ccc}
\hline Computer usage & Less than 2 years & More than 2 years \\
\hline $\mathrm{N}$ & 5 & 75 \\
$\%$ & 6 & 94 \\
\hline
\end{tabular}

Table 7. Formal training.

\begin{tabular}{ccc}
\hline Formal training received? & Yes & No \\
\hline $\mathrm{N}$ & 53 & 27 \\
$\%$ & 66 & 34 \\
\hline
\end{tabular}


Table 1 to Table 7 show the demographic data which have been gathered from the research respondents. Based on the data that has been gathered, it can be noticed from Table 1 that majority of the respondents were females. It is reported that $86 \%$ of the respondents were female and only $14 \%$ of the respondents were male. According to the Malaysia Educational Statistics by the Educational Planning and Research Division (2020), it states that $71 \%$ of the teachers are females and $29 \%$ is reported to be males and this statistic clearly portrays that the teaching profession is conquered my females. As for the age group, $91 \%$ of them are reported to be less than 50 years old and $9 \%$ of them are more than 50 years old. In addition, in this research, $40 \%$ of the respondents were primary school teachers, $39 \%$ were teachers in secondary schools and $21 \%$ were teachers from international and private schools. $29 \%$ of them from SMK schools, $23 \%$ from SMK schools, $21 \%$ from private and international schools, $10 \%$ from SJKC, 9\% from boarding schools (SBP) and 8\% from SJKT schools around Klang Valley. Looking into their teaching experience, $56 \%$ of the respondents have less than 10 years of teaching experience and $44 \%$ of them are teaching for more than 10 years. $6 \%$ of those polled have been using computers for less than two years. The bulk of responders which is $94 \%$ had been using computers for more than two years. As for the last statement in this section, 66\% respondents responded that they have received formal training on the usage of ICT but the majority, 57\% falls into the category of not receiving any formal trainings for ICT.

\subsection{ICT Knowledge Level Possessed by English Language Teachers}

Table 8. ICT knowledge level possessed by English language teachers.

\begin{tabular}{ccccc}
\hline Statement & No Capability & Fair & Good & Excellent \\
\hline Knowledge of graphic application & $\mathrm{N}=4$ & $\mathrm{~N}=20$ & $\mathrm{~N}=40$ & $\mathrm{~N}=16$ \\
& $(5 \%)$ & $(25 \%)$ & $(50 \%)$ & $(20 \%)$ \\
Knowledge on Word processors & $\mathrm{N}=0$ & $\mathrm{~N}=4$ & $\mathrm{~N}=36$ & $\mathrm{~N}=40$ \\
(Pages, Microsoft Word) & $(0 \%)$ & $(5 \%)$ & $(45 \%)$ & $(50 \%)$ \\
Knowledge on Spread sheet & $\mathrm{N}=2$ & $\mathrm{~N}=18$ & $\mathrm{~N}=42$ & $\mathrm{~N}=18$ \\
$\quad$ (Numbers, Excel) & $(2.5 \%)$ & $(22.5 \%)$ & $(52.5 \%)$ & $(22.5 \%)$ \\
Knowledge on Power point application & $\mathrm{N}=2$ & $\mathrm{~N}=6$ & $\mathrm{~N}=39$ & $\mathrm{~N}=33$ \\
(Keynote, Microsoft PowerPoint) & $(2.5 \%)$ & $(7.5 \%)$ & $(49 \%)$ & $(41 \%)$ \\
& $\mathrm{N}=4$ & $\mathrm{~N}=11$ & $\mathrm{~N}=33$ & $\mathrm{~N}=32$ \\
Knowledge on E-mailing & $(5 \%)$ & $(14 \%)$ & $(41 \%)$ & $(40 \%)$ \\
Knowledge on Internet Browsing & $\mathrm{N}=2$ & $\mathrm{~N}=14$ & $\mathrm{~N}=34$ & $\mathrm{~N}=30$ \\
& $(2.5 \%)$ & $(17.5 \%)$ & $(42.5 \%)$ & $(37.5 \%)$ \\
\hline
\end{tabular}

Research Question 1: What is the ICT knowledge level possessed by English language teachers? Table 8 displays the findings of the knowledge level acquired by English language teachers in the use of ICT. As for knowledge on graphic applications, $25 \%$ have fair knowledge, $50 \%$ have fair knowledge and $20 \%$ of the participant have excellent knowledge. $50 \%$ of the respondents have excellent 
knowledge, followed by $45 \%$ having good grasp of it and only $5 \%$ are fair in word processing since it is one of the most significant and commonly utilised applications in teaching and learning processes. For knowledge on spread sheet, a majority of $50 \%$ possess an excellent knowledge and only $2.5 \%$ classify themselves as no capability in using it. A big percentage of $49 \%$ have good knowledge on Powerpoint application and a minimal number of $2.5 \%$ regard themselves have no capability in using the Powerpoint application. As for knowledge on e-mailing, $41 \%$ voted having good knowledge followed by $40 \%$ having excellent knowledge, with $14 \%$ who are fair and $5 \%$ with no capabilities in using the e-mailing application. As for the knowledge possessed on internet browsing, all respondents fall into the category of no capability $2.5 \%$, fair $17.5 \%$, good $42.5 \%$ and excellent $37.5 \%$ respectively.

\subsection{English Language Teachers' Attitudes toward the Use of ICT}

Table 9. English language teachers' attitude towards the use of ICT.

\begin{tabular}{|c|c|c|c|c|}
\hline Items & Disagree & Neutral & Agree & $\begin{array}{l}\text { Completely } \\
\text { Agree }\end{array}$ \\
\hline $\begin{array}{l}\text { a) I can comfortably use ICT as an educational and learning } \\
\text { tool. }\end{array}$ & $\begin{array}{c}\mathrm{N}=3 \\
(4 \%)\end{array}$ & $\begin{array}{l}N=8 \\
(10 \%)\end{array}$ & $\begin{array}{l}N=37 \\
(46 \%)\end{array}$ & $\begin{array}{c}\mathrm{N}=32 \\
(40 \%)\end{array}$ \\
\hline b) The use of ICT stresses me out. & $\begin{array}{c}N=31 \\
(39 \%)\end{array}$ & $\begin{array}{l}N=29 \\
(36 \%)\end{array}$ & $\begin{array}{l}N=15 \\
(19 \%)\end{array}$ & $\begin{array}{l}\mathrm{N}=5 \\
(6 \%)\end{array}$ \\
\hline $\begin{array}{l}\text { c) If something goes wrong while using ICT, I do not know how } \\
\text { to fix it. }\end{array}$ & $\begin{array}{l}\mathrm{N}=26 \\
(32.5 \%)\end{array}$ & $\begin{array}{l}\mathrm{N}=22 \\
(27.5 \%)\end{array}$ & $\begin{array}{l}\mathrm{N}=26 \\
(32.5 \%)\end{array}$ & $\begin{array}{l}\mathrm{N}=6 \\
(7.5 \%)\end{array}$ \\
\hline d) ICT is valuable in teaching and learning. & $\begin{array}{l}\mathrm{N}=2 \\
(3 \%)\end{array}$ & $\begin{array}{l}N=8 \\
(10 \%)\end{array}$ & $\begin{array}{c}N=29 \\
(36 \%)\end{array}$ & $\begin{array}{c}N=41 \\
(51 \%)\end{array}$ \\
\hline e) ICT will change the way teachers teach in class. & $\begin{array}{c}\mathrm{N}=3 \\
(4 \%)\end{array}$ & $\begin{array}{l}N=9 \\
(11 \%)\end{array}$ & $\begin{array}{l}N=33 \\
(41 \%)\end{array}$ & $\begin{array}{c}\mathrm{N}=35 \\
(44 \%)\end{array}$ \\
\hline $\begin{array}{l}\text { f) ICT is not useful for education and learning because it is not } \\
\text { easy to use. }\end{array}$ & $\begin{array}{l}N=36 \\
(45 \%)\end{array}$ & $\begin{array}{l}N=21 \\
(26 \%)\end{array}$ & $\begin{array}{l}N=15 \\
(19 \%)\end{array}$ & $\begin{array}{l}\mathrm{N}=8 \\
(10 \%)\end{array}$ \\
\hline $\begin{array}{l}\text { g) ICT is not a conducive platform for teaching because it is not } \\
\text { easy to use. }\end{array}$ & $\begin{array}{l}N=36 \\
(45 \%)\end{array}$ & $\begin{array}{l}N=28 \\
(35 \%)\end{array}$ & $\begin{array}{c}\mathrm{N}=11 \\
(14 \%)\end{array}$ & $\begin{array}{l}\mathrm{N}=5 \\
(6 \%)\end{array}$ \\
\hline $\begin{array}{l}\text { h) ICT helps teachers to convey their lesson and understand } \\
\text { concepts in a more meaningful way. }\end{array}$ & $\begin{array}{l}\mathrm{N}=5 \\
(6 \%)\end{array}$ & $\begin{array}{l}N=8 \\
(10 \%)\end{array}$ & $\begin{array}{l}N=35 \\
(44 \%)\end{array}$ & $\begin{array}{c}\mathrm{N}=32 \\
(40 \%)\end{array}$ \\
\hline $\begin{array}{l}\text { i) ICT helps teachers to explore new synchronous and } \\
\text { asynchronous platforms that can be used for teaching and } \\
\text { learning. }\end{array}$ & $\begin{array}{l}\mathrm{N}=2 \\
(2.5 \%)\end{array}$ & $\begin{array}{c}N=3 \\
(4 \%)\end{array}$ & $\begin{array}{l}N=41 \\
(51 \%)\end{array}$ & $\begin{array}{l}\mathrm{N}=34 \\
(42.5 \%)\end{array}$ \\
\hline $\begin{array}{l}\text { j) ICT does not favour good teaching because it creates } \\
\text { technical problems. }\end{array}$ & $\begin{array}{l}N=29 \\
(36 \%)\end{array}$ & $\begin{array}{l}N=28 \\
(35 \%)\end{array}$ & $\begin{array}{l}N=16 \\
(20 \%)\end{array}$ & $\begin{array}{l}\mathrm{N}=7 \\
(9 \%)\end{array}$ \\
\hline $\begin{array}{l}\text { k) During this pandemic, ICT helps teacher to enhance their } \\
\text { teaching and learning. }\end{array}$ & $\begin{array}{c}\mathrm{N}=3 \\
(4 \%)\end{array}$ & $\begin{array}{c}N=3 \\
(4 \%)\end{array}$ & $\begin{array}{c}N=33 \\
(41 \%)\end{array}$ & $\begin{array}{c}\mathrm{N}=41 \\
(51 \%)\end{array}$ \\
\hline
\end{tabular}

Research Question 2: What are English language teachers' attitudes toward the use of ICT? Table 9 depicts the English language teachers' attitudes towards the 
use of ICT. Based on the responses collected, $46 \%$ agree and $40 \%$ completely agree that they feel comfortable using ICT as a tool for teaching and learning, meanwhile, only $4 \%$ disagree to the statement. A majority of $39 \%$ disagree and $36 \%$ of the respondents have neutral stand on the use of ICT stresses me out item. This clearly portrays that the use of ICT does not stress out most of the English language teachers. $40 \%$ of the respondents' state that they are not sure on how to fix it if something goes wrong but on the other hand $60 \%$ are able to fix it. The highest percentage of responses $36 \%$ for agree and $51 \%$ for completely agree recorded for the item ICT is valuable in teaching and learning. A majority of $44 \%$ completely agree that ICT changes the way teacher teaches in class and only a handful of them $4 \%$ disagree to it. $45 \%$ of respondents disagree with the statement that ICT is not useful for education or learning due to its inconvenience, but a small group of respondents (10\%) still agreed with the statement. $44 \%$ of the respondents agree and $44 \%$ completely agree to the statement that ICT helps teachers to convey their lesson and understand concepts in a more meaningful way. In contrast, only $6 \%$ disagree and $10 \%$ have neutral stand on it. A majority of $51 \%$ respondents agree that ICT helps teachers to explore new synchronous and asynchronous platforms that can be used for teaching and learning. $36 \%$ of the respondents disagree and the other $20 \%$ agree that ICT is not conductive for good teaching as it creates technical problems. A majority of $41 \%$ agree and $51 \%$ responded completely agree to the use of ICT helps teacher to enhance their teaching and learning during pandemic.

\subsection{Level of ICT Use by English Language Teachers for Teaching and Learning Purposes}

Table 10. Level of ICT use by English language teachers for teaching and learning purposes.

\begin{tabular}{lccc}
\hline Items & Never & Seldom & Often \\
\hline a) Teaching and learning for specific subjects. & $\mathrm{N}=7$ & $\mathrm{~N}=24$ & $\mathrm{~N}=49$ \\
& $(9 \%)$ & $(30 \%)$ & $(61 \%)$ \\
b) Finding and accessing information and & $\mathrm{N}=5$ & $\mathrm{~N}=18$ & $\mathrm{~N}=57$ \\
educational materials. & $(6 \%)$ & $(23 \%)$ & $(71 \%)$ \\
c) Doing presentations. & $\mathrm{N}=5$ & $\mathrm{~N}=28$ & $\mathrm{~N}=47$ \\
& $(6 \%)$ & $(35 \%)$ & $(59 \%)$ \\
d) Preparing lessons. & $\mathrm{N}=9$ & $\mathrm{~N}=16$ & $\mathrm{~N}=55$ \\
& $(11 \%)$ & $(20 \%)$ & $(69 \%)$ \\
e) Communicating with students. & $\mathrm{N}=10$ & $\mathrm{~N}=25$ & $\mathrm{~N}=45$ \\
& $(13 \%)$ & $(31 \%)$ & $(56 \%)$ \\
f) Communicating with colleagues. & $\mathrm{N}=12$ & $\mathrm{~N}=21$ & $\mathrm{~N}=47$ \\
& $(15 \%)$ & $(26 \%)$ & $(59 \%)$ \\
g) Monitor, track and assess student progress and & $\mathrm{N}=9$ & $\mathrm{~N}=25$ & $\mathrm{~N}=46$ \\
performance. & $(11 \%)$ & $(31 \%)$ & $(58 \%)$ \\
h) As a dashboard to report students school based & $\mathrm{N}=8$ & $\mathrm{~N}=33$ & $\mathrm{~N}=39$ \\
assessment level. & $(10 \%)$ & $(41 \%)$ & $(49 \%)$ \\
\hline
\end{tabular}


Research Question 3: What is the level of ICT use by English language teachers for teaching and learning purposes? In this section, eight Likert scale items were used to measure English language teachers level of ICT use. For each item, respondents are required to tick on either never, often or seldom scale. Table 10 presents that data obtained for this section. A majority of $61 \%$ respondents often use ICT for teaching and learning for specific subjects and just $9 \%$ responded they never use ICT for this. Next, $23 \%$ the research respondents claim that they seldom use ICT to access information and educational materials but on the other hand $71 \%$ agree the often use of ICT in accessing the materials. Gençlter (2015) emphasised that in order for language learning to be successful in an English classroom, teachers need to explore appropriate activities using current emerging technology platforms. 59\% often use ICT for presentations and only $6 \%$ responded that they never use ICT for presentation. When it comes to the ICT use in preparing lessons, a majority of $69 \%$ chose the often scale. $56 \%$ often use ICT to interact with students meanwhile seldom and never scale recorded at $31 \%$ and $13 \%$ respectively. As for communicating with colleagues, 59\% respondents fall under the scale of often and only $15 \%$ state never. When it comes to monitoring and evaluating students' progress or keeping track of student achievement, 58\% say they often use ICT. Last but not least, $49 \%$ respondents often use ICT as a dashboard to report students school based assessment level.

\subsection{Challenges Faced by English Language Teachers in Using ICT for Teaching and Learning}

Table 11. Challenges faced by English language teachers in using ICT for teaching and learning.

\begin{tabular}{lccc}
\hline Items & Never & Seldom & Often \\
\hline a) Lack of in-house training/technical support. & $\mathrm{N}=7$ & $\mathrm{~N}=49$ & $\mathrm{~N}=24$ \\
& $(9 \%)$ & $(61 \%)$ & $(30 \%)$ \\
b) Lack of time. & $\mathrm{N}=8$ & $\mathrm{~N}=43$ & $\mathrm{~N}=29$ \\
& $(10 \%)$ & $(54 \%)$ & $(36 \%)$ \\
c) Limited knowledge on fully utilising ICT. & $\mathrm{N}=17$ & $\mathrm{~N}=38$ & $\mathrm{~N}=25$ \\
& $(21 \%)$ & $(48 \%)$ & $(31 \%)$ \\
d) Limited understanding of integrating ICT into & $\mathrm{N}=17$ & $\mathrm{~N}=44$ & $\mathrm{~N}=19$ \\
teaching and learning. & $(21 \%)$ & $(55 \%)$ & $(24 \%)$ \\
e) Lack of synchronous and asynchronous learning & $\mathrm{N}=17$ & $\mathrm{~N}=43$ & $\mathrm{~N}=20$ \\
platform that supports teaching and learning. & $(21 \%)$ & $(54 \%)$ & $(25 \%)$ \\
\hline
\end{tabular}

Research Question 4: What are the challenges faced by English language teachers in using ICT for teaching and learning? Table 11 illustrates the challenges faced by English language teachers in using ICT for teaching and learning. A total number of five Likert-scale items were asked to measure the challenges faced by the respondents. Most respondents (61\%) indicate that lack in-house training and technical support is seldom a problem for them. 54\% of them seldom and 
$36 \%$ of them often have lack of time to fully utilise the use of ICT in teaching and learning. Moreover, $48 \%$ respondents seldom face challenges when they have limited knowledge when it comes to fully utilising ICT. 55\% of respondents sometimes have limited understanding on integrating ICT into the teaching and learning practices. 54\% of research respondents seldom face challenges when there is a lack of synchronous and asynchronous learning platforms that assist teaching and learning. According to the findings of the study, English language teachers seldom experience difficulties in incorporating ICT into their teaching and learning routines and acclimating to the new learning environment.

\section{Discussion}

The findings of the study can be broken down into four categories which are the knowledge level possess by English language teachers in using ICT, the attitude English language teachers show towards ICT, the use of Information Communication Technology (ICT) possessed by English language teachers and the challenges faced by English language teachers in using ICT as a teaching and learning platform.

The aim of research question one was to examine the level of knowledge of English teachers in using ICT. From the results obtained, it can be interpreted that the teachers' level of ICT knowledge is generally good. They were only excellent when it comes to utilising mundane application such as word processing, spreadsheets, power point, e-mailing and internet browsing which are the most widely and often used in the teaching profession. The quantitative study by Moganashwari \& Parilah (2013) affirms that respondents are very familiar with everyday use such as word applications and internet browsing. The Diffusion of Innovations theory by Rogers (2003) dovetail well in this research as knowledge in technology is being seen as an important variable which influences the other variables such as attitude, perceived usefulness of ICT and behavioural intention of use of ICT.

The next finding answers research question two on the attitude English language teachers towards the use of ICT. The data obtained indicate that instructors have an optimistic attitude towards the use of ICT. The result acquired is in compliance with the research that has been carried out by Shah \& Empungan (2015) which demonstrated the majority of the respondents have positive attitude towards the usage of Information Communication Technology (ICT) in teaching and learning. The Davis Technology Acceptance Model (TAM) is consistent with the findings of the study. According to the findings, it can be observed that $46 \%$ of respondents agree that they are comfortable using ICT as a tool for teaching and learning. As a big percentage of $51 \%$ completely agree that ICT is valuable in teaching and learning we should implement and reinforce the use of ICT in the field of education. Moreover, $51 \%$ agree that ICT helps teachers to explore new synchronous and asynchronous platforms that can be used for teaching and learning. Majority respondents $51 \%$ completely agree that ICT changes and enhanced their teaching and learning process during the recent 
Covid-19 outbreak.

The following finding concern the research question three about the use of Information Communication Technology (ICT) possessed by English language teachers. Looking into the Technology Acceptance Model (TAM), it is stated that the respondents' attitude towards ICT will decide the actual system in use. According to the findings, majority of respondents used ICT to teach and learn specific subjects, to communicate with students, to communicate with colleagues, to monitor and evaluate students' progress, to keep track of students' performance, and as a dashboard to report students' school-based assessment level. It is also seen that more than half the respondents have positive attitude towards the use of ICT in teaching and learning. This finding is parallel to the study done by Coban \& Atasoy (2019) which is said that teachers had positive attitudes for their self-development in the use of ICT. From the data obtained, it can clearly be concluded that the model is appropriate for this study as it is widely being used in the teaching profession.

The fourth finding of the study is on the challenges English language teachers face when using ICT. From the data obtained, it can be said that most of the English language teachers seldom face challenges when using ICT for teaching and learning. Despite from the challenges listed, there were several other challenges highlighted by the English language teachers in the comment section. The challenges which were highlighted are, low internet coverage, excessive workload, no proper guidelines and the infrastructures in rural areas which are not developed. The system and service quality deficiencies, the excessive workload, among other obstacles, could have a negative impact on the intention to use and contribute to the resistance of teachers to the online educational and learning environment (Awang et al., 2019).

To summarise the findings of the study, it can be proved that there is a significant relationship between the variables used in this study. A multiple regression test was conducted through SPSS version 27 to identify the significant relationship between the knowledge, attitude and the use of ICT among English language teachers. The results show a significant effect on the use of ICT among English language teachers $(\mathrm{F}(2,78)=14.38), \mathrm{p}=.00)$ with $\mathrm{R}_{\text {adj }}^{2}=0.25$, suggesting that $25 \%$ of the variance can be explained by the combination of the knowledge level and the attitude of English language teachers'. Hence, the knowledge of English language teachers is a significant predictor of the perceived ICT use, $\beta=.24, t(79)=2.33, p=.02$. Meanwhile, the attitude of English language teachers is a significant predictor of the perceived ICT use as well, $\beta=.38, t(79)=$ $3.67, p=.00$. Therefore, this research strongly emphasised that the knowledge level and the attitude possessed by English language teachers influences the actual use of Information Communication Technology (ICT).

\section{Conclusion, Implementation and Recommendation}

Education is a purposeful endeavour and educators play a vital role in creating 
holistic individuals who will contribute to the society and country in the future. As overall, the researchers directed the article to the right audience, and it has met the objectives of the study. Rapid advancement of technology has greatly impacted on online education. The availability of online teaching and learning platform will continue to grow in response to dynamic changes in education. As a responsible educator, taking effective and progressive steps to convey an effective teaching and learning lesson should be prioritised when it comes to the profession. In addition, the use of ICT in classrooms during online teaching and learning (T\&L) process can also produce a holistic human capital in line with the goals in the National Education Blueprint 2013-2025. Using technology and media in teaching and learning, teachers can create $21^{\text {st }}$-century learning that has credibility and competence to conduct efficient and effective teaching and learning platform. In accordance with the learning objectives of the $21^{\text {st }}$ century which is to produce students who could compete in the global stage, the usage of ICT in teaching and learning is vital. Online teaching and learning is a medium to unearth ICT skills among students. Therefore, online teaching and learning environment will surely meet the needs of $21^{\text {st }}$-century learning by integrating the use of ICT. It can be concluded that the availability of online teaching and learning platform will continue to expand in response to dynamic changes in the environment and education.

The results of this study only highlight the English language teachers' knowledge, their attitude and the use of ICT. Therefore, future studies should focus more on the challenges faced by both teachers and students when using synchronous and asynchronous ICT platforms. Moreover, this study just highlighted ICT use in general among educators. Therefore, this study calls out for future researchers to focus on a specific learning platform that is widely being used among English Language teachers such as Digital Educational Learning Initiative Malaysia (DELIMA) so that the data obtained can be more precise and it would be helpful for the policy makers in the Ministry level to identify the limitations and further improve the education system as well as the educational platforms which are being used currently. In addition, this study just focused on schools around Klang Valley. Further studies should be conducted all over Malaysia or around the globe in order to generalise the findings of the study. As this quantitative study only used a questionnaire as the main instrument to collect the data from the respondents, it is suggested for future researchers to include other data collection instruments such as interviews and document analysis to collect more in-depth data about the teachers' attitudes, use of ICT and the challenges that they encountered when using ICT in teaching and learning.

\section{Conflicts of Interest}

The authors declare no conflicts of interest regarding the publication of this paper.

\section{References}

Ahuja, K., Kim, D., Xhakaj, F., Varga, V., Xie, A., Zhang, S. et al. (2019). EduSense: Prac- 
tical Classroom Sensing at Scale. Proceedings of the ACM on Obile, Wearable and Ubiquitous Technologies, 3, Article No. 71. https://doi.org/10.1145/3351229

Al-Munawwarah, S. F. (2014). Teachers Perceptions on the Use of Ict in Indonesian EFL Learning Context. English Review: Journal of English Education, 3, 70-80.

Awang, H., Aji, Z. M., Osman, W. R. S., Nasir, A. A., Deli, M. M., Hamat, W. Y. W. et al. (2019). Virtual Learning Environment (VLE) Implementation Strategy: An Analysis of Practicality for Google Classroom Implementation in Malaysian Schools. Journal of Educational Research \& Indigenous Studies, 2, 1-16.

Awang, H., Aji, Z. M., Yaakob, M. F. M., Osman, W. R. S., Mukminin, A., \& Habibi, A. (2018). Teachers' Intention to Continue Using Virtual Learning Environment (VLE): Malaysian Context. JOTSE, 8, 439-452. https://doi.org/10.3926/jotse.463

Aydin, H., Ozfidan, B., \& Carothers, D. (2017). Meeting the Challenges of Curriculum and Instruction in School Settings in the United States. Journal of Social Studies Education Research, 8, 76-92. https://dergipark.org.tr/en/pub/jsser/issue/32449/360844

Beketova, E., Leontyeva, I., Zubanova, S., Gryaznukhin, A., \& Movchun, V. (2020). Creating an Optimal Environment for Distance Learning in Higher Education: Discovering Leadership Issues. Palgrave Communications, 6, Article No. 66.

https://doi.org/10.1057/s41599-020-0456-x

Beri, N., \& Sharma, L. (2019). Teachers' Attitude towards Integrating ICT in Teacher Education. International Journal of Innovative Technology and Exploring Engineering, 8, 285-295.

Cavas, B., Cavas, P., Karaoglan, B. \& Kisla, T. (2009). A Study on Science Teachers' Attitudes toward Information and Communication Technologies in Education. The Turkish Online Journal of Educational Technology, 8, 20-32.

Coban, O., \& Atasoy, R. (2019). An Examination of Relationship between Teachers' Self-Efficacy Perception on ICT and Their Attitude towards ICT Usage in the Classroom. Cypriot Journal of Educational Sciences, 14, 136-145. https://doi.org/10.18844/cjes.v14i1.3636

Davis, F. D. (2003). Acceptance of Information Technology. MIS Quarterly, 13, 319-339. https://doi.org/10.2307/249008

Dixit, M., \& Kaur, M. (2015). Attitude of Teachers Trainees towards ICT Teaching. International Journal of Pure and Applied Researches, 1, 169-174.

Educational Planning and Research Division (2020). Malaysia Educational Statistics 2020. https://www.moe.gov.my/menumedia/media-cetak/penerbitan/quick-facts/3719-quickfacts-2020/file

Ekberg, S., \& Gao, S. (2018). Understanding Challenges of Using ICT in Secondary Schools in Sweden from Teachers' Perspective. The International Journal of Information and Learning Technology, 35, 43-55. https://doi.org/10.1108/IJILT-01-2017-0007

Gençlter, B. (2015). How Does Technology Affect Language Learning Process at an Early Age? Procedia-Social and Behavioral Sciences, 199, 311-316.

https://doi.org/10.1016/j.sbspro.2015.07.552

Ghavifekr, S., \& Rosdy, W. A. W. (2015). Teaching and Learning with Technology: Effectiveness of ICT Integration in Schools. International Journal of Research in Education and Science, 1, 175-191.

Hashemi, A., \& Kew, S. N. (2021). The Barriers to the Use of ICT in English Language Teaching: A Systematic Literature Review. Journal of Information and Communication Technologies, 3, 77-88.

Kamaruddin, K., Abdullah, C. A. C., \& Idris, M. N. (2017). Integrating ICT in Teaching 
and Learning: A Preliminary Study on Malaysian Private Preschool. International Journal of Academic Research in Business and Social Sciences, 7, 1236-1248. https://doi.org/10.6007/IJARBSS/v7-i11/3561

Kaur, S. (2012). Attitude of Students towards Use of ICT in Higher Education. International Journal of Computer Science and Technology, 3, 194-197.

Mahajan, R., Agrawal, R., Sharma, V., \& Nangia, V. (2016). Analysis of Challenges for Management Education in India Using Total Interpretive Structural Modelling. Quality Assurance in Education, 24, 35-122. https://doi.org/10.1108/QAE-07-2013-0030

Moganashwari, K., \& Parilah, M. S. (2013). Knowledge, Attitude and Use of ICT among ESL Teachers. In Proceeding of the Global Summit on Education (pp. 185-199). Organised by WorldConferences.net.

Nardi, P. M. (2018). Doing Survey Research: A Guide to Quantitative Methods. Routledge. https://doi.org/10.4324/9781315172231

Ndibalema, P. (2014). Teachers' Attitudes towards the Use of Information Communication Technology (ICT) as a Pedagogical Tool in Secondary Schools in Tanzania: The Case of Kondoa District. International Journal of Education and Research, 2, 1-16.

Nickolas, S., \& Drury, A. (2021, May 19). How Stratified Random Sampling Works. Investopedia.

https://www.investopedia.com/ask/answers/032615/what-are-some-examples-stratified -random-sampling.asp

Papanastasiou, E. C., \& Angeli, C. (2008). Evaluating the Use of ICT in Education: Psychometric Properties of the Survey of Factors Affecting Teachers Teaching with Technology (SFA-T3). Journal of Educational Technology \& Society, 11, 69-86.

Robinson, L. (2009). A Summary of Diffusion of Innovations. Changeology.

Rogers, E. (2003). Diffusion of Innovations (5th ed.). The Free Press.

Shah, P. M., \& Empungan, J. L. (2015). ESL Teachers' Attitudes towards Using ICT in Literature Lessons. International Journal of English Language Education, 3, 201-218. https://doi.org/10.5296/ijele.v3i1.7158

Silverthorne, C., \& Wang, T. H. (2001). Situational Leadership Style as a Predictor of Success and Productivity among Taiwanese Business Organizations. The Journal of Psychology, 135, 399-412. https://doi.org/10.1080/00223980109603707

Suparjan, S. (2021). Integrating Information and Communication Technology in Elementary Schools: Teachers' Attitudes and Barriers. Ta'dib, 24, 149-163. https://doi.org/10.31958/jt.v24i1.2584

Thang, S. M., Nambiar, R. M., Wong, F. F., Jaafar, N. M., \& Amir, Z. (2015). A Clamour for More Technology in Universities: What Does an Investigation into the ICT Use and Learning Styles of Malaysian 'Digital Natives' Tell Us? The Asia-Pacific Education Researcher, 24, 353-361. https://doi.org/10.1007/s40299-014-0185-2

Venkateswar, M., Gopikanta, S., \&Rajashree, B. (n.d.). Attitude of Teachers about the Use of Information and Communication Technology (ICTs) in Teaching-Learning Process. In Education for Social Inclusion, Sustainable Development and Empowerment (pp. 1-15). Research Gate.

https://www.researchgate.net/publication/339089160 Attitude of Teachers about the Use of Information and Communication Technology ICTs in Teaching-Learning Process

Wilson, S., Lydiah, N., \& Pachomius, W. (2015). School's Preparedness in Information Communication Technology Integration in Teaching and Learning in Public Secondary Schools. A Case of Kieni East Sub-County Nyeri County, Kenya. IOSR Journal of Humanities and Social Science, 20, 90-99. 